\title{
Czym jest pejzaż językowy (linguistic landscape)?
}

\author{
What is the linguistic landscape?
}

Bogumila Góral

(Poznań)

\begin{abstract}
The language that is present in our environment, words and images displayed and exposed in public spaces are the interest of a relatively recent and rapidly growing study referred to as linguistic landscape (LL). The highest density of signs can be found in cities, especially in the main shopping streets and industrial areas. The study of LL can provide important insights on phenomena which occur in the cities, it can reflect language tendencies and social relations. Hence, the analy sis of LL adresses the issues of multilingualism, language policy, cultural diversity and language contacts. It also strongly relates to national identity, globalisation and the spread of English.
\end{abstract}

\section{Wprowadzenie}

Spacerując ulicami miasta z latwością zauważamy różne napisy: na znakach drogowych, reklamach, sklepach, restauracjach, pubach, plakatach, graffiti. Ze wszystkich stron otaczają nas znaki językowe. Autorzy tych znaków zalożyli, że przechodnie potrafią odczytać i zrozumieć ich treść. Dominacja przekazu wizualnego we wspólczesnym świecie sprawia, że miasto nieustannie do nas mówi, a my często nie jesteśmy tego świadomi. Język obecny w naszym środowisku, słowa i towarzyszace im obrazy ukazane w miejscach publicznych są przedmiotem badań szybko rozwijającej się nowej 
dziedziny badań - tzw. pejzażu językowego (linguistic landscape) Pojęcie linguistic landscape po raz pierwszy zostało użyte przez kanadyjskich badaczy Landry/Bourhis (1997), którzy zwrócili uwage na język obecny w przestrzeni publicznej jako glówny wskaźnik postaw językowych dostarczający istotnych informacji na temat witalności i wzajemnych relacji grup społecznych, zwłaszcza na obszarach dotkniętych konfiktami społeczno-językowymi. Landry/ Bourhis (1997: 25) zaproponowali następujaca definicję pejzażu lingwistycznego:

The language of public road signs, advertising billboards, street names, place names, commercial shop signs, and public signs on government buildings combines to form the linguistic landscape of a given territory, region, or urban agglomeration.

$Z$ definicji tej wynika, że pejzaż językowy dotyczy języka pisanego, który pojawia się w sferze publicznej. Najwięcej znaków językowych pojawia się w miastach, a szczególnie w jego częściach związanych $z$ handlem i przemyslem. To wlaśnie w miastach najbardziej rozwinęlo się piśmiennictwo. Złożone formy koegzystencji mieszkańców miast i zachodzace między nimi skomplikowane interakcje wymagaly form komunikacji wolnych od ograniczeń, jakie związane są z ulotnością mowy. Zróżnicowanie językowe, spoleczne i kulturowe sprawia, że w miastach występuje najwięcej procesów językowych. Stąd linguistic landscape mogłoby być z powodzeniem zastapione pojęciem linguistic cityscape ${ }^{1}$.

W ostatnim czasie obserwujemy wzrost zainteresowania ta nowa dziedziną badań. Po pierwsze, ma na to wplyw coraz większa migracja ludności, a co za tym idzie coraz większa różnorodność językowa. Stą, linguistic landscape mogloby być zastapione również pojęciem multingual cityscape. Po drugie, w rezultacie globalizacji pojawia się bardzo dużo wielojęzycznych reklam. I po trzecie, ponieważ metoda

1 Pojęcie cityscape używane jest w obrębie geografii kultury i w planowaniu przestrzennym, których badania opisywane są w czasopiśmie akademickim „Cityscape”. 
badawcza polega na zrobieniu zdjęć wszelkim tekstom pojawiającym się w przestrzeni publicznej miast, powszechność aparatów cyfrowych (również tych w telefonach komórkowych) w dużym stopniu ulatwia rejestrowanie badań terenowych. Dodatkowym ulatwieniem jest dostępność wszelkiego rodzaju nośników cyfrowych, na których można przechowywać duże ilości danych.

\section{Funkcje pejzażu językowego}

Pejzaż lingwistyczny wiąże się z pojęciem komunikacji i może stanowić dobre źródło informacji o społeczeństwie, które zamieszkuje dany obszar. To ludzie sa autorami znaków językowych - to oni wieszaja plakaty, projektuja znaki drogowe i reklamy w formie billboardów czy ulotek, wymyślają nazwy ulic, placów, sklepów, restauracji, naklejaja ogłoszenia na przystankach autobusowych i na latarniach ulicznych. I jednocześnie to właśnie ludzie zwracaja uwage na docierające do nich informacje i je interpretuja, a czasem pomijają lub zupelnie ignorują. Przestrzeń miejska jest idealnym miejscem do prezentowania swoich pogladów i do przekazywania wszelkiego rodzaju informacji. Jak podkreśla Ben-Rafael (2009: 43), obok architektury i przechodniów, pejzaż językowy stanowi główny składnik obrazu miasta, tego, w jaki sposób dane miejsce postrzegane jest zarówno przez odwiedzających, jak i spoleczność lokalną. Pejzaż językowy oddaje charakter, „osobowość" miasta, która wyróżnia go spośród innych miejsc i sprawia, że jest zapamiętywane. Ponadto, jest jedynym aspektem przestrzeni miejskiej, który jest pod ciagłym i bezpośrednim wplywem czynników spolecznych. Pojawienie się nowych sklepów, instytucji, wprowadzenie nowych technologii, gadżetów, zmieniajace się wystawy sklepowe sprawiają, że w dużych aglomeracjach miejskich nowe obiekty pejzażu językowego pojawiaja się w bardzo szybkim tempie.

W celu zinterpretowania znaczenia docierajacych do nas sygnalów, ich celu i kontekstu, w którym występuja, należy poruszyć kwestie semiotyczne, których glównym elementem jest znak. Badania pejzażu lingwistycznego skupiają się wlaśnie na znaku językowym i na 
określaniu jego funkcji informacyjnej i funkcji symbolicznej (Cenoz/ Gorter 2008: 1) w przestrzeni miejskiej. Funkcja informacyjna określa granice terytorialne danej grupy językowej w celu wykazania, że w komunikacji może być używany jeden lub więcej języków. Z kolei funkcja symboliczna odnosi się do wartości i statusu, w jakich są postrzegane te języki przez daną grupę językową w porównaniu do innych grup. Użycie języka mniejszości może w bezpośredni sposób pozytywnie wplynąć na poczucie tożsamości danej grupy społecznej. Landry/Bourhis stwierdzili (1997: 27): ,the symbolic function of the linguistic landscape is most striking in settings where language has emerged as the most important dimension in ethnic identity."

Na przyklad kierowani względami uczuciowymi Baskowie obecność języka baskijskiego w przestrzeni publicznej postrzegają jako symbol swojej tożsamości. Język baskijski nie posiada więc wylącznie funkcji informacyjnej, gdyż każdy może odczytać informacje w języku hiszpańskim. Z kolei sytuacja w Szkocji, gdzie język gaelicki jest praktycznie nieobecny w pejzażu językowym, wskazuje na to, że nie jest on językiem cenionym i posiada slaby status w społeczeństwie. Ponadto, jeśli język mniejszości jest niedostępny i zabroniony w edukacji, może w końcu zupelnie zaniknąć. Jak zauważają Landry/Bourhis (1997: 29):

absence of the in-group language from the linguistic landscape can lead to group members devaluing the strength of their own language community, weaken their resolve to transmit the language to the next generation, and sap their collective will to survive as a distinct language group.

Te wszystkie symptomy są obecne w przypadku języka gaelickiego.

Język, który pojawia się na znakach, może nawet wplynać na zmianę zachowań językowych, np. widząc język angielski, społeczeństwo może zaczać go częściej używać. W rezultacie pejzaż językowy odzwierciedla witalność językowąi dostarcza nam cennych informacji o kontekście socjolingwistycznym, co może być uzupelnieniem danych zebranych na podstawie wywiadów i ankiet. 


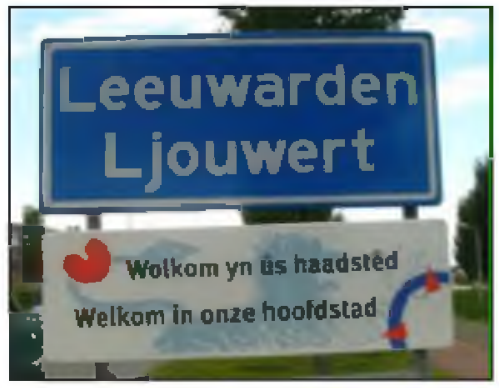

Zdjęcie 1. Top-down sign

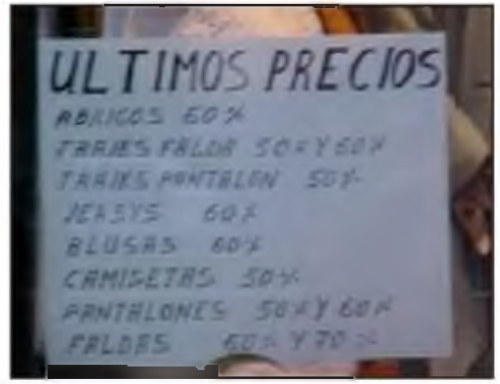

Zdjęcie 2. Bottom-up signs

\section{Polityka językowa}

Pejzaż lingwistyczny zajmuje się językiem pisanym zarówno na znakach prywatnych/nieoficjalnych, jak i oficjalnych/publicznych, podlegającym regulacjom prawnym. W związku $z$ tym poruszana jest często kwestia polityki językowej obowiązującej na danym obszarze. Znaki publiczne, tzw. top-down signs (Zdjęcie 1) ${ }^{2}$, stworzone sa pod nadzorem władz i odzwierciedlają charakter polityki językowej; są to np. znaki uliczne, nazwy ulic, placów, parków, budynków publicznych, ostrzeżenia.

Znaki prywatne, tzw. bottom-up signs (Zdjęcie 2), np. nazwy sklepów, reklamy, napisy na bankach, restauracjach, biurach, charakteryzuje większa swoboda tworzenia; zalicza się do nich również graffiti i plakaty.

Restrykcyjność regulacji prawnych różni się w zależności od danego kraju, stanu czy prowincji. Jedną z najbardziej znanych jest Karta Języka Francuskiego (Charte de la langue française) z 1977, znana jako Ustawa nr 101 (Loi 10I) w Québecu (Backhaus 2009). Dla większości mieszkańców tej kanadyjskiej prowincji (zamieszkanej przez 7 milionów ludności) pierwszym językiem jest język fran-

2 Zdjęcia od 1-6 pochodzą z: Gorter, D. i Cenoz, J. (2008): Minority languages in linguistic landscape: Basque and Frisian, Ikerbasque / University of the Basque Country, konferencja w Barcelonie 16.10.2008, URL: http://www. demolinguistica.cat/web/DOCS_CRUSCAT/activitats/081016Gorter.pdf [27.01.2010] 
cuski. Społeczeństwo frankofońskie stanowi aż 82\% ludności. Wielu mieszkańców Québecu nie zna angielskiego w ogóle lub posługuje się nim bardzo slabo. Oficjalnym i jedynym językiem urzędowym jest język francuski. Ustawa nr 101 wymagala, aby w takich sferach życia publicznego, jak ustawodawstwo, sąy, administracja, służba zdrowia, nauczanie, ushugi, handel, praca, używać jedynie języka francuskiego. Spowodowało to protesty wśród tzw. anglofońskiej spoleczności Québecu, a także wśród anglojęzycznych mieszkańców Kanady. Szczególnie oburzeni byli wlaściciele sklepów. Urażenie zakazem używania języka innego niż francuski na swoich znakach sprawilo, że wiele przypadków trafilo do sądu. W późniejszym czasie regulacje te zostaly zlagodzone i obecnie dopuszczalny jest język angielski, jednak pod warunkiem, że język francuski jest zawsze na miejscu priorytetowym. Obrona języka i kultury w Québecu przybiera niekiedy absurdalne formy. W sklepach pojawiają się kontrolerzy sprawdzajacy czy towar posiada etykiety z jednostkami miary i symbolami w języku francuskim. Rząd Québecu, świadomy, że frankofoni stanowią większość prowincji, ale mniejszość w stosunku do całej Kanady, wprowadzał ustawy mające na celu zachowanie witalności oraz promocję jezyka francuskiego już od późnych lat 60-tych, kiedy rozpoczynala się tzw. ,cicha rewolucja”.

Kolejny znany przypadek regulacji kwestii języka to tzw. ustawa Toubona wprowadzona w 1994 roku we Francji. Ustawa ta miala chronić język francuski przed naporem angielszczyzny. Minister Jacques Toubon robil wszystko, aby powstrzymać rozprzestrzenianie się anglicyzmów, jednak w 1998 roku jego następca Claude Allegre ogłosił, że język angielski nigdy więcej nie powinien być traktowany jako język obcy. Francuzi nie sa osamotnieni w swojej walce o ochronę języka. Również w Polsce istnieje ustawa, która nakazuje firmom sprzedającym zagraniczny towar umieszczanie ulotek reklamowych, metek lub instrukcji w języku polskim. Z kolei Niemcy starają się ograniczyć wplywy języka duńskiego, którego obecność coraz bardziej pozostawia ślad w ich języku. Na Litwie wprowadzono nakaz używania w interesach wylącznie języka litewskiego, próbując $w$ ten sposób ograniczyć wpływy języka rosyjskiego (The Economist). Innym przykladem jest Katalonia, gdzie istnieje 


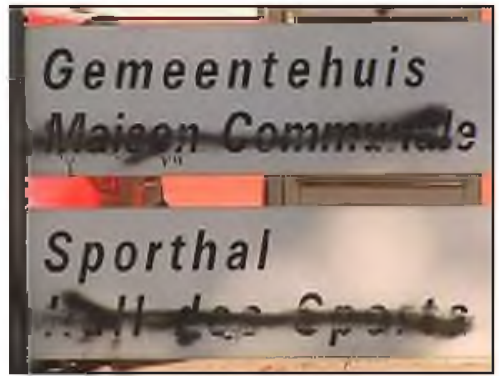

Zdjęcie 3. Zamalowane napisy w Brukseli

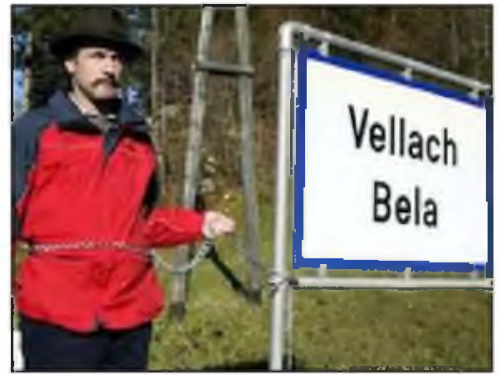

Zdjęcie 4. Karyntia, Austria

obowiązek prawny, który nakazuje, żeby na znakach publicznych i prywatnych pojawial się chociaż w minimalnym stopniu język kataloński. Pejzaż językowy jest tam ściśle monitorowany przez specjalny oddział polityki językowej miejscowych wladz (Cenoz/ Gorter 2009: 57).

\subsection{Konflikty spoleczno-językowe}

Generalnie język dominujacy na danym obszarze jest językiem najbardziej widocznym w pejzażu językowym. Używanie języka dominującego lub języka mniejszości może doprowadzić do konfliktów. Na takich obszarach często zauważa się zamalowane lub przekreślone napisy (Zdjęcie 3). W szczególności problem dotyczy nazw miejsc w języku mniejszości lub w dominującym języku oficjalnym. W Brukseli istnieją ustawy prawne regulujące użycie języka holenderskiego i francuskiego w nazwach ulic, nazwach stacji metra itd. Zamalowywanie znaków jest powszechne w wielu rejonach Europy, gdzie języki mniejszości walczą o swój status. Społeczeństwo w ten sposób nie tylko wyraża swoją dezaprobatę wyboru języka, w jakim pojawia się napis, ale też nie zgadza się z pozycją tekstu lub wielkością liter w poszczególnych napisach na znakach dwujęzycznych lub wielojęzycznych. Nawet jeśli rząd oficjalnie akceptuje znaki dwujęzyczne, wśród społeczeństwa konflikty dotyczące np. dwujęzycznych nazw miejscowości trwają nieustannie, jak wskazuje 
w ostatnich latach użycie języka niemieckiego i słoweńskiego w Karyntii w Austrii (Zdjęcie 4). Na zdjęciu widzimy przedstawiciela mniejszości sloweńskiej, który przywiązal się do znaku lańcuchem, sprzeciwiając się w ten sposób usunięciu znaków z dwujęzycznymi nazwami miejscowości. Zatem jest oczywiste, że pojawienie się różnych języków w przestrzeni publicznej nie tylko odzwierciedla stopień ich użycia, ale również ich władzę i status na danym terenie. Polityka językowa jest również wprowadzana w takich obszarach, jak środki masowego przekazu i edukacja.

Zdaniem Lubasia (Lubaś 1999: 32) w Polsce przemilcza się spory o równouprawnienie mniejszości narodowych odnośnie używania nazewnictwa miejskiego we wlasnych językach regionalnych. Chęć ich publicznego uwidocznienia na sklepach, urzędach posiadają mieszkańcy Ślaska Opolskiego i Kaszubi. Żada się również, aby na nagrobkach można było umieszczać napisy ukraińskie czy bialoruskie.

Ważną część pejzażu językowego stanowią znaki drogowe, które zazwyczaj umieszczane sa przez oficjalne agencje. Od dhuższego czasu są one tematem debat na arenie międzynarodowej. To, w jaki sposób projektowane i uporządkowane sa znaki drogowe, ma wplyw na wyniki badań pejzażu językowego. Amerykańscy projektanci i kontrolerzy znaków drogowych toczą zacięte dyskusje dotyczące dwóch różnych poglądów. Jedna z opinii glosi, że znaki slużą do wskazywania ludziom gdzie i co można znaleźć i co robić lub czego nie robić. Zwolennicy tego poglądu twierdza, że znaki musza być kontrolowane pod względem estetyki. Znaki, w tym również te zawierajace napisy prywatne i komercyjne, postrzegane sa jako forma aktywności terenowej (land activity) i powinny być kontrolowane przez oficjalne instytucje rządowe (Mandelker/Ewald 1988). Przeciwna opinia glosi, że znaki, oprócz wskazywania, spełniaja wiele innych funkcji, np. w obrębie marketingu, reklamy, shużą do znajdowania drogi, dostarczania informacji, kreowania image'u, wizualnie stymulują i kreuja środowisko handlowe (Claus et al. 2004: 1). W tym kontekście większe i bardziej rzucajace się w oczy znaki są cenniejsze. Znaki postrzegane są tutaj nie jako aktywność, lecz raczej jako forma mowy. Stąd można powiedzieć, że znaki 
„krzycza”" w celu zwrócenia naszej uwagi, a to powoduje, że ważną kwestią staje się ich wartość ekonomiczna.

\section{Pejzaż językowy czynnikiem ksztaltującym tożsamość językową}

Badania pejzażu lingwistycznego moga wskazać, jaka grupa językowa zamieszkuje dany obszar, a także może dokładnie określić różnorodność językową i być istotnym czynnikiem w ksztaltowaniu tożsamości językowej. Związane sa z tym procesy regionalizacji i lokalizacji, które lącznie zostaly określone mianem ,glokalizacji” (Gorter 2006a: 82). Te zachodzące jednocześnie procesy wiążą się z poczuciem tożsamości regionalnej i z językiem regionalnym. Przykładem jest Ljouwert/Leeuwarden we Fryzji i Donostia/San Sebastian w Kraju Basków, których pejzaże językowe zostaly porównane przez Cenoz/Gorter (2006). W miastach tych toczy się ciagla walka o przetrwanie języków mniejszości w przestrzeni miejskiej. Zarówno język fryzyjski, jak i język baskijski są zagrożone przez oficjalne języki dominujące: język holenderski i język hiszpański. Język fryzyjski jest obecny w mieście w niewielkim stopniu, gdyż oficjalna polityka językowa zezwala na używanie go jedynie przy określaniu nazw miejsc i nazw ulic. Z kolei w Kraju Basków, oficjalna polityka językowa chroni i promuje język baskijski, który można zauważyć tak często, jak język hiszpański. Pod względem ilości języka angielskiego pojawiającego się na znakach wielojęzycznych, kraje te sa do siebie zaskakujaco podobne. Autorzy (Cenoz/Gorter 2006: 70) podkreślają że język angielski używany na znakach handlowych nie ma na celu przekazania faktycznej informacji, jest on używany raczej ze względu na swoją wartość konotacyjną - brzmi bardziej międzynarodowo i prestiżowo, kojarzy się z nowoczesnością, rozrywką i sukcesem.

Innym przykładem jest Barcelona, której większość mieszkańców jest dwujęzyczna. Języka hiszpańskiego używa się tam ze względu na swoje pochodzenie lub poczucie tożsamości językowej. Język kataloński z kolei jest asymilowany chętnie przez społeczeństwo, 
bo jest językiem klasy średniej, a więc językiem prestiżowym. Stąd pojawienie się różnych języków w mieście odzwierciedla silę, władzę a nawet status ekonomiczny danych grup językowych. Czynne użycie katalońskiego jest również wyraźnym znakiem identyfikowania się z Katalonią (Vila-Pujol 2007: 67).

\section{Metoda badawcza - wielorakie perspektywy}

Tematyka pejzażu językowego cieszy się coraz większym zainteresowaniem przede wszystkim w socjolingwistyce i w lingwistyce stosowanej (Gorter 2006b: 2). Jednak oprócz językoznawstwa pejzaż lingwistyczny czerpie inspiracje również z takich dziedzin naukowych, jak geografia humanistyczna, edukacja, socjologia, polityka, architektura, planowanie przestrzenne, ekonomia. Eksperymenty psychologiczne dotyczace percepcji wizualnej lub badania krajobrazów miejskich w geografii kultury również mogą okazać się bardzo cenne. Multidyscyplinarne podejście do badań z pewnością pomaga lepiej zrozumieć pejzaż językowy.

Badania terenowe LL polegają na zebraniu znaków językowych występujących w mieście i na przeprowadzeniu ich wizualnej analizy. Jak już zostalo wspomniane, powszechność aparatów cyfrowych bardzo ulatwia rejestrowanie zebranych danych. Występujajednak trudności związane $z$ wyborem obszaru badań i rodzaju jednostek, jakie chcemy analizować. Należy zastanowić się, gdzie chcemy robić zdjęcia? Czy będą one reprezentować dane miasto, jakiś obszar czy może caly kraj? Czy będziemy brać pod uwagę teksty pojawiające się na ruszających się przedmiotach, takich jak autobusy, taksówki, a nawet koszulki mieszkańców? Pejzaż językowy może się zmieniać z dnia na dzień; niektóre napisy są zdejmowane lub dodawane, inne, na stale wpisane w krajobraz miasta, pozostają niezmienione przez wiele lat. Do analizy jednostek badawczych można podejść $\mathrm{z}$ różnych perspektyw. Duża część badań bazuje na analizie ilościowej obiektów językowych, biorąc pod uwagę obecność specyficznych języków, ich ilość oraz kolejność występowania na znakach dwujęzycznych (Zdjęcie 5) i wielojęzycznych (Zdjęcie 6), wielkość 


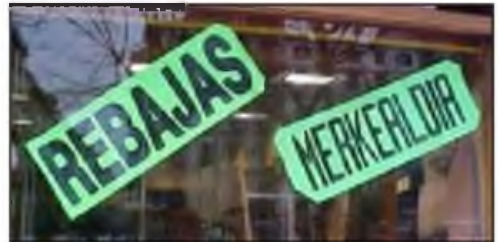

Zdjęcie 5. Znak dwujęzyczny

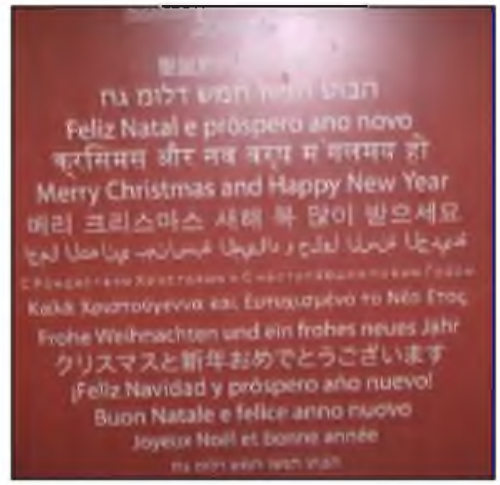

Zdjęcie 6. Znak wielojęzyczny

liter oraz fakt, czy tekst zostal przetlumaczony, a jeśli tak, to czy calkowicie czy czéściowo. Tak przeprowadzona analiza spelnia potrzeby ekologicznego podejścia do badań nad multilingwizmem, gdyż dostarcza informacji na temat nisz specyficznych języków występujacych w językowym ekosystemie (Hult 2009: 91). Ponadto pozwala wyciagnać wnioski na temat spolecznych kwestii związanych z użyciem poszczególnych języków, np. konfliktów społeczno-etnicznych, solidarności i tożsamości wyrażanej poprzez wybór konkretnych języków na znakach oficjalnych i nieoficjalnych.

Badanie pejzażu językowego to również badanie kulturowego dziedzictwa. W języku odzwierciedlona jest kultura $\mathrm{i}$ wieloletnia tradycja pokoleń. Nazewnictwo miejskie to namacalne ślady historii miasta, pozostawione przez ludzi, którzy tam mieszkali, pracowali, tworzyli i bawili się. Wedlug Komisji Europejskiej język jest częścią kulturowego dziedzictwa, bo to właśnie za jego pomoca w najbardziej bezpośredni sposób wyrażamy kulture: ,,Language is the most direct expression of culture; it is what makes us human and what gives each of us a sense of identity." (2005: 2).

UNESCO (2002) podkreśla, że każdy ma prawo wypowiadać się w wybranym przez siebie języku: 
All persons have therefore the right to express themselves and to create and disseminate their work in the language of their choice, and particularly in their mother tongue; all persons are entitled to quality education and training that fully respect their cultural identity; and all persons have the right to participate in the cultural life of their choice and conduct their own cultural practices, subject to respect for human rights and fundamental freedoms.

Stąd podtrzymanie kulturowej i językowej różnorodności powinno być interesem poszczególnych organów zajmujacych się politykąjęzykowa. Pejzaż językowy stanowi bardzo ważny element w zachowaniu istnienia tej różnorodności.

Pejzaż językowy związany jest również z procesem nabywania języków obcych, gdyż stanowi dobry, chociaż nieformalny, materiał językowy (input). Na podstawie obserwacji różnorodnych języków w mieście uczniowie moga dokonać ich wlasnej oceny i podjać decyzje o podjęciu ich nauki. Zatem pejzaż językowy może być doskonała motywacją do nauki języków obcych. Wiadomo również, że dzieci już w bardzo wczesnym wieku zauważają napisy w przestrzeni publicznej. Dobrym przykladem są centra edukacyjne, gdzie pojawiaja się liczne napisy w wielu językach. Taki pejzaż językowy może nie tylko wplynać na wybór języka, ale też z pewnością stanowi doskonaly material do nauki o wielokulturowości i o kontaktach językowych. Dla imigrantów lub turystów znaki są często ich pierwszym kontaktem z nową kulturą w nowym dla nich miejscu. Wykorzystując swoją znajomość języków obcych, starają się oni odczytać treść znaków i w ten sposób zinterpretować nowe środowisko.

\section{Multilingwizm i dominacja języka angielskiego}

Niewatpliwie badania pejzażu językowego wskazuja, że multilingwizm jest zjawiskiem powszechnym we wspólczesnym świecie. Według Cenoz/Gorter (2008: 1) przyczyniają się ku temu: 
- czynniki historyczne i polityczne, takie jak imperializm czy kolonializm,

- czynniki ekonomiczne, takie jak migracja ludności,

- wzrost komunikacji między różnymi częściami świata i użycie języków międzynarodowej komunikacji,

- tożsamość społeczna i kulturowa oraz chęć podtrzymania i ożywienia języków mniejszości (dotyczy to obszarów gdzie używa się na co dzień dwóch lub więcej języków),

- nauczanie języków obcych w szkolach,

- względy religijne, które powodują przenoszenie się ludności do innych krajów.

W kontekście europejskim różnorodność językowa jest zjawiskiem bardzo cennym. Wedlug Komisji Europejskiej (2005: 2) jest ona źródłem bogactwa i pomostem do solidarności i wzajemnego zrozumienia:

It is this diversity that makes the European Union what it is: not a 'melting pot' in which differences are rendered down, but a common home in which diversity is celebrated, and where our many mother tongues are a source of wealth and a bridge to greater solidarity and mutual understanding.

Stąd należy szanować i dbać o wszystkie języki w taki sam sposób, ulatwiając użytkownikom ich naukę i gwarantując prawo używania wybranego języka na wszystkich płaszczyznach życia społecznego (Denison 1990: 137).

Jak podkreślają Cenoz/Gorter (2008) Europa nie jest tak różnorodna pod względem ilości języków jak inne kontynenty. Tylko $3,5 \%$ języków na świecie jest pochodzenia europejskiego. Jednak z powodu naplywu dużej ilości imigrantów i uchodźców, w ostatnich latach różnorodność językowa Europy wzrasta. Najbardziej widoczne jest to w dużych miastach europejskich, gdzie języki naplywowe są używane na wielu płaszczyznach życia codziennego. Najbardziej popularne języki imigrantów w Europie to: arabski, berberyjski, turecki, kurdyjski, hindi, punjabi (pendżabski) i chiński. Należy zaakceptować fakt, że nowoczesne spoleczeństwa XXI wieku są coraz 
bardziej heterogeniczne, tj. wielojęzyczne i wielokulturowe. Wedhug autorów (Cenoz/Gorter 2008), przekonanie, że jedno państwo posiada jeden język jest już nieaktualne, gdyż obecnie coraz częściej obserwujemy skomplikowane interakcje między różnymi językami i kulturami zachodzące na jednym obszarze. Zróżnicowanie etniczne, społeczno-kulturowe, religijne, handlowe pozostawia ślady w języku, czyni go coraz bardziej różnorodnym. Proces ,glokalizacji" sprawia, że powstaje kulturowa mieszanka, ogromna różnorodność ubrań, muzyki, żywności i języków. W rezultacie, aby komunikować się z przechodniami, w miejscach publicznych nieustannie powstają nowe slowa, tworza się hybrydy i fuzje odmian lokalnych i globalnych. Na naszych oczach toczy się niejako rewolucja językowa ustalająca nowe reguly językowe, które pozwalają na wprowadzenie nowej skladni, wymowy i nowych słów, którym towarzyszą często dodatkowe formy opisu, takie jak dźwięki czy obrazy. Niezliczone sytuacje, w których języki wchodza ze sobą w kontakt doprowadzają do wielu form dwujęzyczności. Wszystkie te zjawiska mogą być doskonale utrwalone w pejzażu językowym.

Badając pejzaż językowy można zaobserwować różnice między znakami oficjalnymi a prywatnymi. Huebner (2006), który badal pejzaż językowy różnych dzielnic Bangkoku, zaobserwowal, że napisy instytucyjne na znakach oficjalnych są generalnie napisane w języku tajskim lub w tajskim i w angielskim, a wszelkie napisy o charakterze komercyjnym pojawiają się w innych językach. Ponad połowa zbadanych przez niego tekstów jest napisana za pomoca więcej niż jednego alfabetu. Najczęściej występują kombinacje alfabetu tajskiego i lacińskiego oraz alfabetu tajskiego, lacińskiego i chińskiego. Wielojęzyczność przejawia się zarówno na znakach jednojęzycznych napisanych w różnych językach, jak i na znakach wielojęzycznych. Oprócz tego Huebner wykazal, że obecność języka angielskiego widoczna jest nie tylko w pejzażu językowym, ale również wplywa na język tajski pod względem pisowni oraz na poziomie fonetycznym, leksykalnym i syntaktycznym.

Pejzaż językowy Azji badał również Backhaus (2006), który skupił się jedynie na dwujęzycznych i wielojęzycznych znakach Tokio. Napisy w więcej niż jednym języku stanowily $20 \%$ calkowitej 
liczby napisów ulic, które badał. Na znakach dwujęzycznych pojawial się najczęściej japoński i angielski, ale również występowały znaki dwujęzyczne i wielojęzyczne z obecnością innych języków, takich jak chiński czy koreański. Obecność języka angielskiego na znakach dwujęzycznych i wielojęzycznych byla bardzo wyraźna, zawierało go aż 98\% tego typu znaków. Backhaus zauważyl, że język angielski częściej występuje na znakach prywatnych niż na znakach oficjalnych. Ponadto podkreślil, że Japonia nie jest tak homogenicznym językowo krajem, jak się powszechnie sadzi, oraz stwierdzil, że pejzaż językowy stanowi ważny wkład w badania nad wielojęzycznością na świecie.

\subsection{Wszechobecność języka angielskiego - korzyść czy zagrożenie?}

W przestrzeni miejskiej pojawia się coraz więcej wielojęzycznych znaków ze szczególnym udzialem języka angielskiego, który staje się wszechobecny. Angielski jest odzwierciedleniem ekonomicznego i kulturowego procesu globalizacji, który określany jest też jako McDonaldyzacja pejzażu językowego (Heller 2003). Język ten określany jest mianem współczesnej lingua franca, gdyż posiada fenomenalnie szeroki zasięg geograficzny, spoleczny i funkcjonalny. Angielski to język międzynarodowego biznesu, polityki i dyplomacji. Jego sukces jako języka globalnego tkwi w tym, że umożliwia on prowadzenie rozmów z innymi bez względu na dzielące nas granice. To również język komputerów i Internetu. Często jest obecny na znakach w przestrzeni publicznej razem z językiem lokalnym. $Z$ jednej strony ma to na celu oddanie kosmopolitycznego charakteru miasta, jest symbolem nowoczesności i postępu, a z drugiej strony jest również wyrazem lokalizacji, gdyż podkreśla patriotyzm i lokalną dumę mieszkańców. W krajach nieanglojęzycznych, obok języka lokalnego, najczęściej występuje właśnie język angielski. Jako glówny język nauki i technologii we wspólczesnym świecie rozprzestrzenia się w rejonach, gdzie nigdy nie był powszechnie używany. Jest również głównym językiem popkultury, co jest widoczne w reklamach. Według Ben Rafael et al. (2006: 12) wszechobecność 
języka angielskiego sprawia, że może on być określany już jako nonforeign language.

Język angielski może pełnić funkcję informacyjna, np. gdy kierowany jest do turystów lub imigrantów, i funkcję symboliczna, gdyż odgrywa ważną rolę również dla mieszkańców miast, którzy postrzegają go jako język prestiżowy, związany z sukcesem, z rozrywką i postępem (dotyczy wspomnianej wcześniej wartości konotacyjnej). Często nie liczy się treść, jaka przekazuje znak, ale właśnie język, w jakim jest napisany lub odróżniające się pismo, co sprawia, że znak wyróżnia się spośród innych i zwraca uwage przechodniów. Jak zauważa Handke (2008: 367), charakterystyczna cechą w nazewnictwie polskich obiektów miejskich jest chęć wlaścicieli i użytkowników do podwyższenia prestiżu obiektu poprzez używanie deskrypcji obcojęzycznych, np. Sklep Baby, Bar Micado, Boutique Jeanette.

Z drugiej strony jednak uważa się, że język angielski może stanowić zagrożenie dla rozwoju różnorodności językowej, gdyż dominuje nad użyciem innych języków (Phillipson 1992). Dla wielu społeczeństw tryumf języka angielskiego oznacza zniknięcie ich własnej mowy. Lingwiści szacuja, że spośród około 7000 języków świata, każdego tygodnia kilka z nich ulega zapomnieniu. Ofiarami globalizacji są m.in. języki ludów zamieszkujących Papuę Nowa Gwineę, Indonezję, Nigerię, język eyak na Alasce, język catawba w Massachusetts. Język to nie tylko medium komunikacji, to również źródlo kultury narodu i jego tożsamości. W wielu krajach dominacja angielskiego, który niesie ze sobą kulturę amerykańska. wraz z językiem niszczy kulturę lokalną. Sama polityka językowa nie jest w stanie zapobiec dominacji języka angielskiego w świecie, jednak ochrona zagrożonych języków jest możliwa. Uświadomienie sobie istoty i wagi języka dla kultury narodowej może doprowadzić do ponownego wprowadzenia programów nauczania danego języka w lokalnych szkolach. Tak się stało w przypadku języka rdzennej mniejszości zamieszkującej Québec, których język mohawk jeszcze do niedawna był niemal zapomniany. Dzięki zainteresowaniu organizacji rządowych i spolecznych do swojej dawnej świetności powracają też takie języki jak walijski i islandzki. 


\section{Podsumowanie}

Z powyższych rozważań wynika, że glównym zadaniem badań pejzażu lingwistycznego jest odzwierciedlenie sytuacji socjolingwistycznej danego terenu poprzez opis różnorodności językowej i kulturowej, odzwierciedlenie stopnia użycia danych języków i powiązanie tych zjawisk z polityką językową oraz poczuciem tożsamości językowej. Jako nowa dziedzina ciesząca się coraz większym zainteresowaniem przede wszystkim w socjolingwistyce, pejzaż językowy ukazuje związek pomiędzy językiem a różnorodnymi atrybutami społecznymi, takimi, jak np. religia, etniczność, narodowość, klasy społeczne czy rasa. Ponadto wskazuje, że wielojęzyczność jest bardzo powszechnym zjawiskiem. Szczególnie widoczny jest język angielski, który pełni rolę języka międzynarodowej komunikacji, a jego dominacja spowodowana jest przede wszystkim turystyka i procesami globalizacji. Pejzaż językowy, przedstawiając prawdziwy, „żywy" i autentyczny język używany w bardzo dynamiczny sposób, potwierdza, że miasto może być cennym źródłem informacji o spoleczeństwie, które w nim żyje.

\section{Bibliografia}

Backhaus, Peter (2006): „Multilingualism in Tokyo - A look into the linguistic landscape. International". Journal of Multilingualism, 3 , 52-66.

Backhaus, Peter (2009): „Rules and regulations in Linguistic Landscaping: A Comparative Perspective". [w]: Shohamy, Elana/Gorter, Durk Linguistic Landscape: Expanding the Scenery, Nowy Jork: Routledge. $157-172$.

Ben-Rafael, Eliezer et al. (2006): „Linguistic Landscape as Symbolic Construction of the Public Space: The Case of Israel". International Journal of Multilingualism, 3(1), 7-30.

Ben-Rafael, Eliezer (2009): ,A sociological approach to the study of Linguistic Landscapes". [w]: Shohamy, Elana i Gorter, Durk Linguistic Landscape: Expanding the Scenery, Nowy Jork: Routledge, 40-54. 
Cenoz, Jason/Gorter, Durk (2006): „The Linguistic Landscape and Minority Languages". International Journal of Multilingualism, 3(1), 67-80.

Cenoz, Jason/Gorter, Durk (2008): El estudio del paisaje lingüistico, URL: http://depot.knaw.nl/3852/ [27.01.2010]

Cenoz, Jason/Gorter, Durk (2009): „Language Economy and Linguistic Landscape". [w]: Shohamy, Elana/Gorter, Durk Linguistic Landscape: Expanding the Scenery, Nowy Jork: Routledge, 55-69.

Claus, Robert James et al. (2004): „Street Graphics and the Law: a Flawed perspective I \& II", [w]: Signline (46 \& 47), URL: http://www.signs. org/Government/SignlineList.cfm [27.01.2010]

Denison, Daniel R. (1990): Corporate culture and organizational effectiveness. Nowy Jork: Willey.

Gorter, Durk (2006a): ,Further Possibilities for Linguistic Landscape Research". [w]: Gorter, D. (ed.) Linguistic Landscape: A New Approach to Multilingualism, 81-89.

Gorter, Durk (2006b): „Introduction: the Study of the Linguistic Landscape as a New Approach to Multilingualism". International Journal of Multilingualism 3(1), 1-6.

Gorter, Durk/Cenoz, Jasone (2008): Minority languages in linguistic landscape: Basque and Frisian. Ikerbasque / University of the Basque Country, konferencja w Barcelonie 16.10.2008, URL: http://www.demolinguistica.cat/web/DOCS_CRUSCAT/activitats/081016Gorter.pdf

Handke, Kwiryna (2008): Socjologia języka. Warszawa: PWN.

Heller, Monica (2003): „Globalization, the new economy and the commodification of language". Journal of Sociolinguistics, 7, 473-492.

Huebner, Thom (2006): „Bangkok's Linguistic Landscapes: Environmental Print, Code Mixing, and Language Change". International Journal of Multilingualism 3, 31-51.

Hult, Francis M. (2009): „Language ecology and linguistic landscape analysis". [w]: Shohamy, Elana/Gorter, Durk: Linguistic Landscape: Expanding the Scenery. Nowy Jork: Routledge, 88-103.

Komisja Europejska (2005): „A New Framework Strategy for Multilingualizm", URL: http://europa.eu/languages/servlets/Doc?id=913 [27.01.2010]

Landry, Rodrigue/Bourhis Richard Y. (1997): „Linguistic landscape and ethnolinguistic vitality: An empirical study". Journal of Language and Social Psychology 16(1): 23-49.

Lubaś, Wladysław (1999): „Co jest teraz ważne w polskiej polityce językowej?" [w]: Mazur, Jan: Polska polityka językowa na przełomie 
tysiącleci. Lublin: Centrum Języka i Kultury Polskiej dla Polonii i Cudzoziemców, 25-35.

Mandelker, Daniel R./Ewald, William R. (1971, 1988): Street Graphics and the Law. Chicago: American Planning Association.

Phillipson, Robert (1992): Linguistic Imperialism. Oxford: Oxford University Press.

The Economist (2001): „Angielski bez granic”, URL: http://www.marhan. pl/index.php/jezyk-angielski/38-artykuy/76-angielski-bez-granic [27.01.2010]

Unesco (2002): Unesco Universal Declaration on Cultural Diversity. Adopted by the $31^{\text {st }}$ session of the General Conference, 2 November 2001, Paris, France, URL: http://unesdoc.unesco.org/ images/0012/001271/127160m.pdf [27.01.2010]

Vila-Pujol, Maria Rosa (2007): ,Spanish in Spain: the Sociolinguistics of Bilingual Areas, Sociolinguistics of Spanish in Catalonia”. International Journal of the Sociology of Language 184, 59-77. 